\title{
Les Drômois sous Napoléon, 1800-1815
}

\author{
Jean-Paul Bertaud
}

\section{(2) OpenEdition}

\section{Journals}

Édition électronique

URL : https://journals.openedition.org/ahrf/1059

DOI : 10.4000/ahrf.1059

ISSN : 1952-403X

Éditeur :

Armand Colin, Société des études robespierristes

Édition imprimée

Date de publication : 1 mars 2001

Pagination : 136

ISSN : 0003-4436

\section{Référence électronique}

Jean-Paul Bertaud, «Les Drômois sous Napoléon, 1800-1815 », Annales historiques de la Révolution française [En ligne], 323 | janvier-mars 2001, mis en ligne le 10 avril 2006, consulté le 24 avril 2022. URL : http://journals.openedition.org/ahrf/1059 ; DOI : https://doi.org/10.4000/ahrf.1059

Ce document a été généré automatiquement le 24 avril 2022.

Tous droits réservés 


\title{
Les Drômois sous Napoléon, 1800-1815
}

\author{
Jean-Paul Bertaud
}

\section{RÉFÉRENCE}

Les Drômois sous Napoléon, 1800-1815, par J.-P.Bernard, C.Magnan, J.Sauvageon, R.Serre, C. Seyve, M. Seyve, R. Pierre, Crest, Notre Temps, 1999, 400 pages, chronologie, index, cartes, tableaux et illustrations. Préface de J.-P.Bertaud.

1 L'ouvrage se place dans la continuité de la série «240000 Drômois et la Révolution» dont trois tomes sont parus de 1986 à 1996. Les Drômois ont-ils accepté, ou subi, la dictature napoléonienne? Comment ont-ils vécu les mutations imposées? Quelles furent les répercussions sur la société, sur l'économie locale, sur la démographie et la santé, sur les multiples situations de la vie quotidienne des mesures prises par le pouvoir, de l'ouverture des marchés nouveaux ou de la disparition des courants traditionnels d'échange? Le livre fait par des érudits qui connaissent fort bien leurs archives locales et savent les mettre en œuvre avec méthode étudie d'abord la période du Consulat et de l'Empire triomphant jusqu'en 1809. Se trouve ainsi présenté et analysé l'investissement par l'administration napoléonienne du solide bastion républicain où la résurgence du jacobinisme s'était fait particulièrement sentir à la fin du Directoire. Une deuxième partie est consacrée au temps des crises et à un effondrement de l'Empire d'abord bien accueilli avant que le département n'applaudisse au retour de l'île d'Elbe et ne connaisse une amorce de guerre civile. Une troisième partie intitulée «Vivre dans la Drôme sous Napoléon» enrichit notre connaissance sur les mouvements de population, sur une économie qui ne réussit pas ici à décoller, sur la vie sociale et culturelle où l'étude des loisirs, des jeux et des fêtes est particulièrement bien venue. 